\title{
TEACHING READING COMPREHENSION BY USING GROSSWORD PUZZLE GAMES FOR JUNIOR HIGH SCHOOL STUDENTS
}

\author{
'VINA AISYAH ZEDE, ${ }^{2}$ IBNU SUBROTO, ${ }^{3}$ BRYAN KALBU ADHI \\ IUniversitas Bina Sarana Informatika, 2Universitas Bina Sarana Informatika, \\ 3Universitas Bina Sarana Informatika \\ vina.daz@bsi.ac.id, ibnusubroto04I2@gmail.com,bryan.bka@bsi.ac.id
}

\begin{abstract}
The purpose of this research is to know the effectiveness of Teaching Reading Comprehension by using Crossword Puzzle games for Junior High School Students. The research was conducted in MTs Nurani in 2018. The writer was conducted research approximately 1 month, the writer started the research on October 1st 2018 until October 31st 2018. This research uses descriptive qualitative method. The data were collected through observation and learning process. This teaching contains planning and implementation of using crossword puzzle games to make students more interested in reading. The result of this research indicate that: (1) Using crossword puzzle games in test on reading can facilitate students remember vocabulary contained in reading text, (2) Using crossword puzzle games as a teaching material can make students more fun in reading, (3) Students got new vocabulary and help students understand the meaning of new vocabulary in the process of teaching and learning
\end{abstract}

Keywords: Crossword puzzle, Reading Comprehension

\section{INTRODUCTION}

Teaching is activity of guiding and facilitating learning, enabling the learner to learn and setting the conditions for learning. Then, teaching is acting so as deliberately and directly to facilitate learning. While what is done to achieve the purpose of teaching may be almost infinitely diverse, it is the purpose of the activities, not the activities, which is definite. Similarly, teaching of important kinds is undertaken in many different context and by many people in diverse roles. English as a foreign language has four skills, namely listening, reading, speaking and writing. The four skills are supported by the learning of language elements. Reading is very important because by reading understanding skill, people can give the ideas through writing and exchange the information with others.

According to Cremin in (Putra, 2014), "teaching and learning English is, at its richest, an energizing, purposeful and imaginatively, vital experience for all involved, developing youngsters' competence, confidence and creativity as well as building positive attitudes to learning." It means that teaching and learning English must have competence to make a creativity to building positive attitudes.

Based on Johnson Walker in (Lesiak, 2015), "teaching means instructing, informing as a master; delivering any doctrine or art or words to be learned; or giving intelligence." 
In this definition, teaching involved to instructing, delivering or giving words to learned to improve intelligence.

On reference of Mangal in (Putra, 2014), "teaching is a quite serious task or activity undertaken by the teachers to produce desirable changes in their students." In this case, teaching is serious activity for teachers to produce desirable changes in their students. According to Kimble Garmezy in (Lesiak, 2015), defines teaching as "showing or helping someone to learn how to do something, giving instructions, guiding in the study of something, providing with knowledge, causing to know or understand." Based on definition, teaching is activity to facilitate learner, which is giving, guiding, providing and causing something until the learner understand. Based on Cameron in (Putra, 2014), "teaching and learning are not two sides of the same coin, but are essentially different activities, although they both take place in the public area of the classroom." It means that teaching and learning are different activities but in the same area. On reference of Brown in (Lesiak, 2015), "teaching should be defined with a term of learning, because "teaching" facilitates a learning process, gives the learner an opportunity to learn and sets the conditions essential for learning." In this definition, teaching is facilitates a learning process, gives the learner information to learn.

From all of explanation above, the writer concluded that teaching is activity for teachers to facilitating and guiding the learner, delivering or giving words to learn to improve intelligence, giving information to learner, providing with knowledge, and causing to understand to learner. Reading is about understanding written texts. Without reading, somebody do not understand what the meaning of written text. It is a complex activity that involves both perception and thought. There are some kinds of reading used teaching in English language, such as extensive reading, silent reading, reading aloud, and reading comprehension. Reading comprehension is one of reading skill that taught in junior and senior high school until at university. Many teachers believed that the students were also less motivated to look up at their dictionary to check the meaning of vocabulary. Most of students expected translation from their clever friends and teacher. As the consequence, they did not fully understand the text. As being known that understanding is the main target in reading skills. It is believed that teaching reading at schools was not interesting to the students. It is because reading class was monotonous. Teacher should be selective in choosing teaching media. In the writer's opinion, teaching English on reading skill using crossword puzzle games was one of teaching aid in which students' were given chance to learn English more fun.

Based on Smith (in Puspitorini, 2017), "reading is more just a pleasant, interesting and informative experience." In this case, reading is a fun activity, interesting and informative experience to learner. On reference of River (in Manan, 2017), "reading is the most important activities in language class, not only as source information and extending one's knowledge." Based on definition, reading is important activities in language class, to find information and increase knowledge. According to Otong (in Iwan, 2016), "reading is an activity to comprehend and dig deep into the information as well as explore the mind of the information conveyer stated in a text. To implement the thinking ability into reading is by knowing the reading comprehension of the reader." In this definition, reading is activity to deep into the information as well as explore the mind. On reference of Cohen (in Sah, 2012), has explained that " reading is viewed as an interaction between 
the text and the reader." Based on definition, reading can make interaction between the text and the reader, when the reader has read the text, it is indirect the reader interact with the text. According to Ruddel (in Gani, Yusuf, \& Susiani, 2016), "reading is the act of constructing meaning while transacting with the text." It means that reading is an activity which can build a meaning when the reader can information reading on the text. On reference of Grabe (in Munjayanah, 2016) reading is often defined in simple statements much like following, "reading is the process of receiving and interpreting information encoded in language from via the medium of print" or "comprehension occurs when the reader extract and integrates various information from the texts and combines it with what is ready known". Based on definition, reading is process to receiving and interpreting information from the text and combines it with what is ready to known.

The writer concludes that based on theories above, reading is the important activity in language, because reading can make interaction between the text and the reader. Reading also give information to reader also process to receiving and interpreting information from the text. Reading comprehension is one of reading skill that taught in junior and senior high school until at university. Many teachers believed that the students were also less motivated to look up at their dictionary to check the meaning of vocabulary. Most of students expected translation from their clever friends and teacher. As the consequence, they did not fully understand the text. As being known that understanding is the main target in reading skills. It is believed that teaching reading at schools was not interesting to the students. It is because reading class was monotonous. Teacher should be selective in choosing teaching media. In the writer's opinion, teaching English on reading skill using crossword puzzle games was one of teaching aid in which students' were given chance to learn English more fun.

Based on Chall (in Puspitorini, 2017), "reading comprehension is thus a component which is significant even at the earliest stages of the process of learning to read, and defines the further process learning by reading". Based on definition, reading comprehension is the earliest component of the process learning to read. On reference of Kennedy (in Rahman, 2017), "reading comprehension is the essential of reading evaluation in the most school. Comprehension test is an instrument for assessing the ability of a reader to understand the content of a selection read". It means that reading comprehension is the essential of reading evaluation to know ability of a reader to understand purpose on the text reading. According to Liu in (nugroho, 2017), "many reading comprehension studies consider the extent to which visuals, that is any graphic display that portrays all or some accompanying text's content, help reader to comprehend factual information". In this definition, reading comprehension is to help reader to comprehend information from the text reading. On reference of Razak in (Rahmawati, 2018), points out that reading comprehension is "the ability of the reader to recite the contents of the argumentation, expository, or read a description of a particular topic." Based on definition, reading comprehension is to know the ability of the reader about description or argumentation of the text reading.

Based on the theories above, the writer concludes that, reading comprehension is component which is the earliest stages of the process of learning to read, to know the ability of the reader about description or argumentation of the text reading, also to help reader to comprehend factual information. Crossword is one of media that make reading in 
English more fun. Crossword is puzzle in which words have to written (form numbered clues) vertically and horizontally (up and down) in scales on problem design to test person's knowledge in which words have to written vertically and horizontally in spaces on squared. According to Hornby (in Munjayanah, 2016), "a crossword puzzle is a game in which words have to be fitted across and downwards into spaces with number in a square diagram." It means that, crossword puzzle is game which is have shape of box and fill the blank of box by across also down. Based on Njoroge (in Pinuria, 2013.), defines that "the crossword puzzle is a game that makes the teaching-learning process attractive and fun. And also gives much opportunity for students to practice and repeat the sentence pattern and vocabulary." Based on definition, crossword puzzle games that makes the teaching process more fun.

On reference of Moursund (in Munjayanah et al., 2016), "crossword puzzle is a popular puzzle games which in every case, the puzzle-solver's goal is to solve a particular mentally challenging problem or accomplish a particular mentally challenging task." In this definition, crossword puzzle games is popular games to solve mentally challenging task.

The writer concludes that based on theories above, crossword puzzle games is a game that makes teaching learning process more fun. This game be able to make learner hard think about the answer and to improve reading of learner from new words that learner see. Based on the reasons above, the writer decide to simplify them in reading, the writer try "Teaching Reading Comprehension by using crossword puzzle games for Junior High School Students" study case at 7th grade in MTs Nurani. So, in reading, the children can also be their imagination with word in puzzle.

\section{METHOD}

In writing this paper, the writer uses descriptive qualitative methods of analysis. According to Sandelowski (in Seixas, Smith, \& Mitton, 2018), "qualitative description represents the methodological category that has the least level of inference among the qualitative methods, one that allows "the reading of lines, as opposed to reading into, between, over or beyond the lines". It means that this method make the researcher to write her observation with step by step. The writer gets necessary information for writing this paper by collecting data from the library research means for finding, collecting and selecting the data taken from some books according to the title of this paper. Library study is important things that writer uses to collects data, and collects the material not only from books but also from the internet. The writer also uses field research by teaching directly in the classroom. It means that the position of the writer is a teacher at MTs Nurani at the 7th grade.

\section{FINDINGS AND DISCUSSION}

In the pre-test part, The writer gave worksheet to students, then the writer gave direction what they should do. The students just fill the box after they read the question. Here is the example of the pre-test paper : 


\section{The Weather}

Weather describes the condition of the atmosphere. The condition of the atmosphere may be hot or cold, wet or dry, calm or stormy, clear or cloudy. The layer of gases surrounding the planet Earth is called the Earth's atmosphere. The atmosphere is made up of different gases and acts as a shield protecting life and it also helps maintain a safe temperature on Earth.

The temperature is the degree of hotness or coldness in the air, sometimes called air temperature. A thermometer is the instrument used to measure the temperature of the air or any other substance. The temperature based on the motion of the energy in the air. If the gas molecules in the air move faster, the air temperature will increase.

Humidity is the measurement of water vapor, or the invisible water in the air. Air pressure is the weight of the atmosphere pressing down on the Earth. Air pressure is also called atmospheric pressure. A barometer is used to measure atmospheric or air pressure. It is used by scientists, called meteorologists, who study the weather to forecast changes in the weather.

The change in air pressure has an effect on weather. Air moves from higher pressure to lower pressure, so if there's high and a low nearby, it can be windy as air rushes between the two. High pressure situations are generally associated with fair, sunny weather. Low pressure areas are generally cloudy/rainy areas; strong areas of low pressure bring the stormiest weather.

In higher altitude places, the air pressure decreases because the air is less dense here. However, in lower altitude places, the air pressure increases because the air is denser at lower sea levels.

Wind is caused by air flowing from high pressure areas to low pressure areas. The differences in the pressure is caused by the uneven heating of the Earth's surface by the sun. Some areas of the Earth receive more heat from the sun than other areas. This also results in various wind speeds. A difference between high and low pressure will cause wind, but the greater the difference the stronger the wind.

The rotation of the Earth also has an effect on the direction of the wind. If the Earth did not rotate, the wind would blow in a straight direction. Since the Earth rotates, the wind is deflected from the straight path.

Local winds are created as a result of mountains, vegetation, bodies of water, and other similar natural bodies. This is why local winds may change often, from mild breezes to strong winds in just hours. Local winds cover short distances.

There are several variables that affect the type of weather on the Earth, one is location. Coastal areas may have different weather patterns than mountainous areas. Weather also depends on a place's distance from the equator. 
In summary, the Earth's weather can be warm, cold, windy, dry, rainy, snowy, and different combinations of each. Temperature affects air pressure, wind has an effect on temperatures, and there are other variables affecting the type of weather occurring throughout the world.

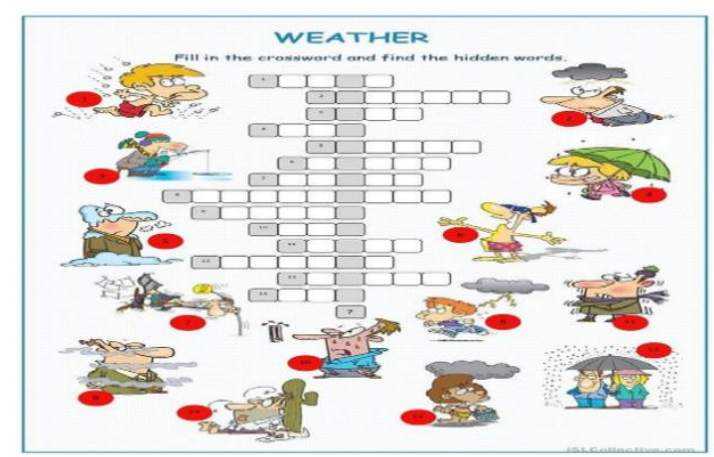

Figure 3. 1: Pre-Test Paper

Table 3.2: The result of pre-test

\begin{tabular}{lll}
\hline No & Student & Score \\
1. & Student A & 60 \\
2. & Student B & 60 \\
3. & Student C & 70 \\
4. & Student D & 70 \\
5. & Student E & 60 \\
6. & Student F & 60 \\
7. & Student G & 60 \\
8. & Student H & 60 \\
9. & Student I & 70 \\
10. & Student J & 70 \\
11. & Student K & 60 \\
12. & Student L & 60 \\
13. & Student M & 60 \\
14. & Student N & 60 \\
15. & Student O & 70 \\
16. & Student P & 70 \\
17. & Student Q & 70 \\
18. & Student R & 60 \\
Total & & 1.150 \\
Average & & 63,88 \\
\hline
\end{tabular}


From the score above, many students did not understand about weather in reading text. Then, some students understand about reading text above. In the next meeting, the students learn about Fruits. Then, the teacher explained the difference between fruits and vegetables. The teacher gives example of illustrated so that students can understand and know how to distinguish it. After the teacher explain about Fruits, the teacher given the students reading text about Fruits to observe as far as which students understand.

\section{Fruits and Vegetables}

Eating fruits and vegetables every day will help prevent disease and give a person a stronger body. They come in all shapes and sizes and add color to any meal. Many are portable also and can provide a quick snack or add to a lunch. There are ten reasons to eat more fruits and vegetables. First, fruits and vegetables provide a wide variety of colors for your meal. A salad of grapefruit slices, mango, bananas, purple grapes and kiwi fruit provides a rainbow effect on a plate. A mixture of colorful vegetables might include red onions, corn, broccoli, and black beans. A good snack is a combination of fruit and nuts. This may include dried cranberries, dried apples, dried peaches, dried pears and dried cherries. These are fruits of different colors. Items of different colors can be put on a pizza. Red and green peppers, black olives, spinach, and mushrooms will provide a colorful treat.

Secondly, fruits and vegetables can be very convenient to eat. Frozen fruits and vegetables usually are picked and frozen immediately, preserving all of the vitamins and minerals. Canned fruits and vegetables are other options. They contain all of the nutrients of fresh. Canned vegetables are already cooked prior to packaging to make an instant addition to a meal. Freeze-dried fruits can be crunchy and good for snacks. Juice from many fruits and vegetables is also available.

Third, fruits and vegetables contain fiber which is needed for good intestinal health. Some have more fiber than others. Apples, blackberries, pears, and raspberries are fruits especially high in fiber. Lentils, lima beans, pinto beans, and spinach are high-fiber vegetables. Some fruits and vegetables which have lower but still good amounts of fiber are bananas, blueberries, broccoli, green beans and sweet potatoes.

Fourth, fruits and vegetables are low in calories. A healthy plate should have one-half filled with fruits and vegetables. High-calorie foods cause weight gain.

Fifth, eating fruits and vegetables may prevent certain diseases, such as high blood pressure, heart disease and some types of cancer.

Sixth, fruits and vegetables contain many important vitamins and minerals. Calcium is necessary for good bones and teeth. Vitamin $\boldsymbol{C}$ keeps gums healthy and can heal wounds. Vitamin A keeps eyes and skin healthy and can help prevent infection. Magnesium is found in pinto beans and spinach. Potassium is a mineral found in Lima and small white beans.

Seventh, there is such a great variety of fruits and vegetables that there is always a different one to try. 
Eighth, fruits and vegetables are a quick snack and more natural and good for you than potato chips and candy. They have fewer calories and fat too.

Ninth, fruits and vegetables can be fun to eat. Some, like apples, crunch. Bananas are rather soft. Some must be peeled. Some are squishy, like raspberries. Carrots are very hard and crunchy to bite when raw. Some people can grow fruits and vegetables in their own yards, making eating them really exciting.

Tenth, it is worth repeating that fruits and vegetables are good for you, taste good, and have lots of vitamins and minerals.

This is the exercise :

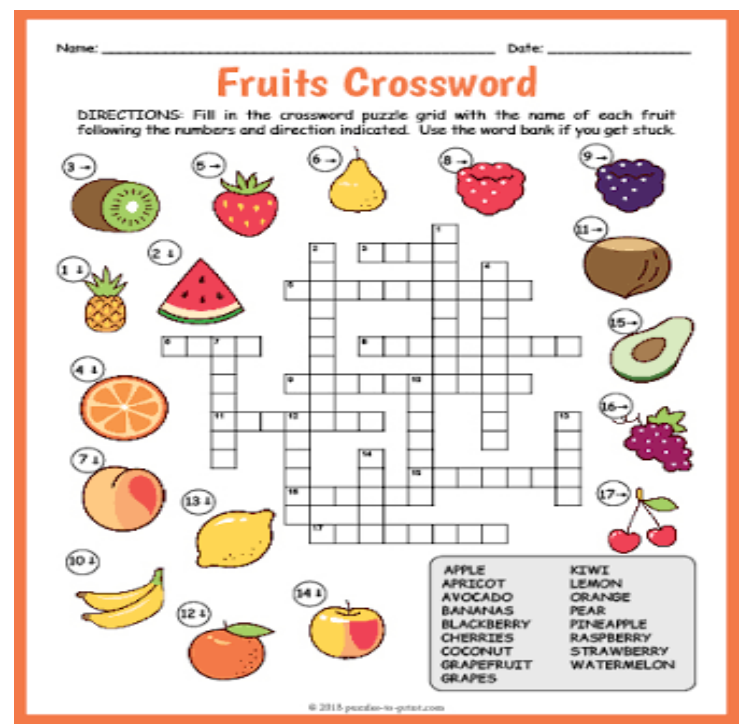

Figure 3.2. Fruits and Vegetables

In this meeting, the teacher makes a group for students to do exercises. After that the teacher collected the students' paper and give them score.

Table 3.2: Score

\begin{tabular}{ll}
\hline Group & Score \\
\hline 1 & 90 \\
2 & 100 \\
3 & 100 \\
4 & 90 \\
Total & $\mathbf{3 8 0}$ \\
Average & $\mathbf{9 5}$ \\
\hline
\end{tabular}


The teacher asked the students to give conclusion about the lesson. After that, the teacher ask the students to keep repeating the lessons provided in their house.In the last meeting, the teacher gives a greeting and warming up as usual so the students can be relax and pay their attention to the lesson. The subject of this meeting is test and evaluation. The teacher explained again about the lesson in the meeting before. After that, the teacher asked the students whether they understand or not about this lesson. If they do not understand, the teacher will explain more and will give students examples until the students understand about the lesson. Then, the teacher distributed a paper test. This test aims to make the teacher know the ability of students' understanding during the lesson. This is the text reading:

\section{Days, Weeks, Months and Years}

My name is tom. Today is my day to learn about days, weeks, months and years! Days. Every time I wake up, it is a new Day! Each day really starts at Midnight (12 O'clock at Night) and ends next Midnight: One Day ; Midnight, Sunrise, Midday, Sunset, Midnight. But I sleep when it is dark, so I only notice the new day when I wake up!

Days Have Names. Each day is special! there are seven different days: Monday, Tuesday, Wednesday, Thursday, Friday, Saturday, Sunday. And that after Sunday, it is Monday again! Round and round every seven days.

Week. Seven days together make a week. A week can be any period of seven days. This is easy! I know what a Day is, and 7 Days make a Week: 1 Week $=7$ Days.

Months. I have also heard people talk about Months ... what are they? there are 12 different months! Each has a different name, and I should try to remember them all (wow!) My dad says a month is about 30 days long, but some months can be longer or shorter. For example April has 30 days, but May has 31 Days! If there are about 30 days in a month, how may weeks is that? My dad says that 30 days is a little longer than 4 weeks. OK, some months are 30 Days, but not all of them. So I don't know exactly how long a month is unless I look it up. But I can remember this: 1 Month $=$ about 30 Days $=$ about 4 Weeks.

Year. My dad says 12 months together make One Year: 1 Year $=12$ Months. He says that a Year is a long period of time. And there are 365 days in a year (but some years are 366 days long if they are a Leap Year) OK, so a Year is 12 Months and a Year is also 365 Days (or 366 Days in a Leap Year) 1 Year $=12$ Months $=365$ (or 366) Days. 
This is the exercise :

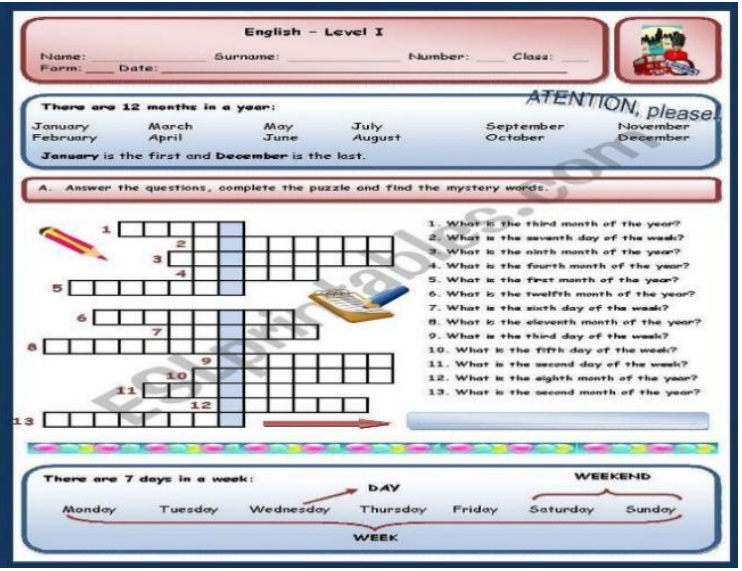

Figure 3.3 : Paper of test

Table 3.4: Score of test

\begin{tabular}{lll}
\hline No & Student & Score \\
& & \\
1. & Student A & 80 \\
2. & Student B & 80 \\
3. & Student C & 85 \\
4. & Student D & 85 \\
5. & Student E & 80 \\
6. & Student F & 70 \\
7. & Student G & 80 \\
8. & Student H & 75 \\
9. & Student I & 85 \\
10. & Student J & 85 \\
11. & Student K & 70 \\
12. & Student L & 75 \\
13. & Student M & 80 \\
14. & Student N & 80 \\
15. & Student O & 80 \\
16. & Student P & 80 \\
17. & Student Q & 85 \\
18. & Student R & 80 \\
Total & & $\mathbf{1 . 4 3 5}$ \\
Average & $\mathbf{7 9 , 7 2}$ \\
\hline
\end{tabular}


The test collected to the teacher, for the given score. Then, the teacher asked the students to give conclusion about this test. After that, teacher asks the students to keep repeating the lessons provided in each house.

\section{Post-Test}

In this part, the teacher gave the students a test to aim ability from the students during the lesson. In the post-test, the teacher found a rising of the students during learning process. This is the text reading:

\section{A day at the zoo}

I took my young daughter to the zoo for the first time recently.

She's a real animal lover. At home she spends all her time playing and walking our pet dog, and to be honest, she's been asking me to take her for a while.

At first I wasn't sure about going because I've always been uncomfortable with zoos. I considered them to be like prisons for wild animals that should be running free, not locked up in cages.

Well, I have to say modern zoos are much better than I remember, the animals have lots of space, they seem well taken care of and we learned a lot. The first thing we saw were the gorillas. They look so human, it's easy to how we are related to them. They don't have tails like chimpanzees and can walk upright a bit.

Next were the elephants. It's amazing how they can pick up food with their trunks. I learned you can tell if they are African or Indian by the size of their ears - African ones have bigger ears.

After that it was the lions, nicknamed the 'kings of the jungle'. We didn't hear any of them roar, but we did get to see them walk about. The males have beautiful manes of hair around their necks. Apparently it's to protect them in fights. I also read that the females do most of the hunting.

My daughter was a little scared of the snakes, I guess a lot of people don't like reptiles. I have to admit any animal with a long thin body and no arms or legs is weird!

The penguins made we laugh, they are so cute! It's strange to think they're a bird that can't fly. While other birds have wings for flying, they have adapted their flippers for swimming.

The other birds I liked looking at were the owls. They have huge eyes, beautiful feathers, and they can turn their necks all the way around. I read their large eyes are to help them see at night, when they are most active.

My daughter was fascinated with the giraffes and their long, long necks. She asked me why they have long necks instead of long legs - good question!

All in all, it was a great day. Next time I'll take her to the aquarium to see the dolphins, sharks and whales.

After that, the students are given to make a group to do the exercise made by the teacher on the white board. The exercises about Animals that the answers using crossword puzzle games. This is the exercise : 


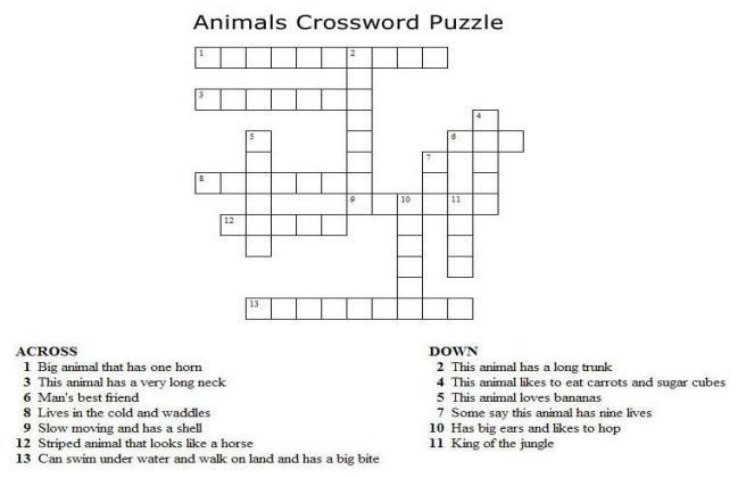

Figure 3.4 : Post-test Paper

The teacher made post-test table result to know ability of students.

Table 3.4 : The result of post-test

\begin{tabular}{lll}
\hline No & Student & Score \\
& & \\
1. & Student A & 85 \\
2. & Student B & 90 \\
3. & Student C & 85 \\
4. & Student D & 85 \\
5. & Student E & 80 \\
6. & Student F & 95 \\
7. & Student G & 85 \\
8. & Student H & 80 \\
9. & Student I & 95 \\
10. & Student J & 95 \\
11. & Student K & 80 \\
12. & Student L & 85 \\
13. & Student M & 85 \\
14. & Student N & 90 \\
15. & Student O & 90 \\
16. & Student P & 85 \\
17. & Student Q & 90 \\
18. & Student R & 85 \\
Total & & $\mathbf{1 . 5 6 5}$ \\
Average & $\mathbf{8 6 , 9 4}$ \\
\hline
\end{tabular}

According of the table above, from 16 students in the class, there are three students fairly active about reading comprehension by using crossword puzzle, five students active about reading comprehension by using crossword puzzle and ten students very active 
about reading comprehension by using crossword puzzle. The writer conclude that in this part, the students can understand and receive the lessons. The teacher also gave evaluation from the student. Finding their mistakes. And gave the students score for all their exercises and test. Finally, the teacher not only teach the student about the lesson, but also make the students understood about the material and successfully accept the materials.

Table 3.5. Evaluation

\begin{tabular}{cll}
\hline Skill & Pre-test & Post-test \\
Reading Comprehension & 63,88 & 86,94 \\
\hline
\end{tabular}

Based on the field research during one month, the writer found that every students has different ability, there are interested in English lesson and there are less interested in English lesson. From 18 students in the classroom, the teacher takes sample of the research. The sample indicated has 63,88 average score for pre-test. After that, the teacher conducted a post-test which has score 86,94 average. It means that the teaching reading comprehension by using crossword puzzle games is effective. From the result table, during the pre-test and the post-test have a significant result. The teacher can use this method to improve reading skill in the classroom specially for $7^{\text {th }}$ grade in Junior High School because this method make teaching learning process more fun and interesting for students. The result that the writer got during field research is by using crossword puzzle, to improve reading skill from students, its effective for students because their can find new vocabulary and how to read it. Then, this method make the students more interest to read the text. Also this method, able to facilitate the students to answer any question.

\section{CONCLUSION}

The writer conclude that teaching reading comprehension by using crossword puzzle games method is very effective for junior high school students, specially to students of MTs Nurani. In this case, the method can improve the ability of students to love reading. The teacher is able to convey the material with intensive and capable of making students explore their thinking becomes more widespread. The influence of crossword puzzle games for the students is to increase knowledge in reading in English, and also to find the vocabulary that have never been on view, and also to increase the vocabulary knowledge of the students. Students can also understand the meaning of the vocabulary that they read. The teacher teaching reading comprehension by using crossword puzzle games started from prepare the lesson plan, the materials and others. Then, the teacher introduces and explains about the material using crossword puzzle games until the students understand.

The difficulties of using crossword puzzle games in teaching reading comprehension are sometimes the students a little confused about the box to write word. This situation make the class became noisy. The teacher have to manage the situation. The advantages of using crossword puzzle games in teaching reading comprehension are to make students enjoy during study English, to make students understand meaning new words, and to help students more easy to understand about the lessons. The disadvantages of using crossword 
puzzle games in teaching reading comprehension are the students a little confused about word to they write, question in teaching reading comprehension is limited, then this situation made the teacher longer to make boxes of crossword puzzle. In the end, the writer suggested for the students of seventh grade to use this method because the method is effectively can improve their reading skill. They can increase their vocabularies by finding many kinds of new vocabularies. For the teacher, they must be prepared well all the materials before teaching learning process. They should find a suitable method that can help them to explain easier and get best understanding from the students. After choosing the method, the teacher should choose the media that can help them also to create an interesting atmosphere for teaching learning process.

\section{References}

Arda, S., \& Doyran, F. (2017). Analysis of Young Learners' and Teenagers' Attitudes to English Language Learning. 9(2), 179-197.

Iwan. (2016). The Effects of Vocabulary and Grammar Mastery on Students 'Reading Skill. $\operatorname{VIII}(2)$.

Latief, H., Khaerunnisa, \& Hamid, R. (n.d.). Exposure Journal 184. 6(2), 184-205.

Lesiak, K. (2015). Teaching English to adolescents. 7, 246-260.

Manan, A. (2017). teaching reading comprehension by using short stories. 404-423.

Munjayanah, S., Training, T., \& Faculty, E. (2016). IMPROVING STUDENTS 'READING COMPREHENSION ( A Classroom Action Research of the Seventh Grade Students $o f$.

Nugroho, agung wahyu. (2017). THE EFFECTIVENESS OF TEACHING READING USING COMIC STRIP TO FACILITATE STUDENTS ' READING COMPREHENSION O N.

Puspitorini, F. (2017). The Correlation Between Students Vocabulary Achievement And Students Reading Comprehension Achievement At The Second Grade of SMPN 30 Bekasi. IX(1), 75-80.

Putra, O. (2014). No Title. The Analysis of Teaching Things through Oral Repetition, $6(45)$.

Rahman, W. laili kurnia. (2017). A Descriptive Study on Teaching Learning Process of Reading of The Eight Grade Students of Mts Miftahul (pp. 67-72). pp. 67-72.

Rahmawati, E. Y. (2018). Analysis of Students $\hat{a} \epsilon^{T M}$ English Reading Comprehension through KWL ( Know-Want-Learn ) Learning Strategies. 2(3), 238-247.

Sah, K. P. (2012). ASSESSMENT AND TEST IN TEACHING AND. 2. 